\title{
A Study of Customer Satisfaction in Administration Procedure at Food Testing Laboratory by SERVQUAL Method
}

\author{
Meike Elsye Beatrix, Titia Izzati, and Gita Septiana \\ Faculty of Enginering \\ Industrial Engineering Program \\ Mercu Buana University, Jakarta, 11650, \\ Indonesia
}

\begin{abstract}
Food Testing Laboratory is the agency that provides services of testing samples of the Original farm. The measurement of customer satisfaction in this instance has not been detected according to the value of the interests of the customer. This study aims to learn the level of customer satisfaction according to the views of customers and find what things need to be evaluated for quality improvement. The research on the methods of dimension 5 uses their Service Quality, i.e. reliability, Responsiveness, Assurance, empathy and also physical evidence. Customer satisfaction measurement is done with the dissemination of a questionnaire on 64 respondents. The results have been analyzed using SERVQUAL method and Diagram of ImportancePerformance Analysis (IPA) that is processed using Microsoft Excel and SPSS Software obtained that 19\% of customers have been feeling very satisfied with the services provided while $81 \%$ were satisfied. Quality improvement priority also needs to be done for 2-dimensional variable guarantee with priority improvements to the 9th variable.
\end{abstract}

Keyword: Customer Satisfaction, Service Quality, Laboratory, Importance Performance Analysis Services.

\section{INTRODUCTION}

At present, many institutions or agencies that sell competing services offer services to their customers. It does not rule out the possibility for agencies that sell products in the form of goods that offer consulting services that are included in the products they sell. This makes competition even tighter to provide customer satisfaction., especially companies engaged in services[1, 2]. there are separate demands for companies that determine "good" or not in serving customers, in terms of purchasing services and complaints related to services offered[3]. This has become a focal point for an institution or agency to carry out services[4].

Food Testing Laboratory is a government-owned laboratory located in the East Jakarta area that provides testing services with a limitation of Animal-based Food Products. The Food Testing Laboratory can provide service consultations either by telephone, e-mail or direct discussion[5]. Consultation provided is in the form of technical consultations and also financial consultations (Testing Costs)[6, 7]. The Food Testing Laboratory will issue a test result certificate for the company within 10-15 working days. Until now, the Food Testing Laboratory has calculated customer satisfaction, but there has been no result of customer satisfaction according to the interests of customers[8-10]. Within 9 months, from January to December 2018 there were around 33 cases of complaints, the majority of which were compulsory regarding the time gain in making certificates or writing errors in the results of certificates. This is the basis of the research goal to determine the level of customer satisfaction also knowing customer satisfaction based on the views of the interests of customers [11, 12], especially for the youth generation[13, 14].

Based on the background above the problems in this study exist in no measurement of customer satisfaction based on the views or values of the interests of the customer[15], so the objectives in this study include :

1. Knowing the level of customer satisfaction with administrative services in the Food Testing Laboratory.

2. Know what things need to be evaluated in order to improve administrative services to customers in the Food Testing Laboratory.

In this study certainly has limitations, the limitations of this study only discuss customer satisfaction with services in the Food Testing Laboratory. This study will not discuss costs and its quantitative. 


\section{METHODOLOGY}

The research on the methods of dimension 5 uses their Service Quality, such as Reliability, Responsiveness, Assurance, Empathy, and Physical evidence. Customer satisfaction measurement is done with the dissemination of a questionnaire on 64 respondents.

\section{III.RESULTS AND DISCUSSION}

In collecting data, the author will tabulate the total results from the data obtained through the distribution of questionnaires to 64 customers, namely recapitulation of the assessment of customer expectations of service and also the actual results received by customers from the services provided.

Table 1. Recapitulation of customer expectations assessment

\begin{tabular}{|c|c|c|c|c|c|c|}
\hline & \multicolumn{5}{|c|}{ Number of answers } & \multirow{2}{*}{ Questions } \\
\cline { 2 - 6 } & $\begin{array}{c}\text { Very } \\
\text { unimportant }\end{array}$ & Unimportant & $\begin{array}{c}\text { Quite } \\
\text { important }\end{array}$ & Important & $\begin{array}{c}\text { Very } \\
\text { Important }\end{array}$ & Total \\
\cline { 2 - 6 } & $(1)$ & $(2)$ & $(3)$ & $(4)$ & $(5)$ & \\
\hline Variable 1 & 0 & 0 & 0 & 26 & 38 & 64 \\
\hline Variable 2 & 0 & 0 & 0 & 33 & 31 & 64 \\
\hline Variable 3 & 0 & 0 & 0 & 36 & 28 & 64 \\
\hline Variable 4 & 0 & 0 & 0 & 5 & 59 & 64 \\
\hline Variable 5 & 0 & 0 & 0 & 5 & 59 & 64 \\
\hline Variable 6 & 0 & 0 & 0 & 22 & 42 & 64 \\
\hline Variable 7 & 0 & 0 & 0 & 43 & 21 & 64 \\
\hline Variable 8 & 0 & 0 & 0 & 25 & 39 & 64 \\
\hline Variable 9 & 0 & 0 & 0 & 32 & 32 & 64 \\
\hline Variable 10 & 0 & 0 & 0 & 12 & 52 & 64 \\
\hline Variable 11 & 0 & 0 & 0 & 12 & 52 & 64 \\
\hline Variable 12 & 0 & 0 & 0 & 26 & 38 & 64 \\
\hline Variable 13 & 0 & 0 & 0 & 43 & 21 & 64 \\
\hline Variable 14 & 0 & 0 & 0 & 22 & 42 & 64 \\
\hline Variable 15 & 0 & 0 & 0 & 15 & 49 & 64 \\
\hline Variable 16 & 0 & 0 & 0 & 32 & 32 & 64 \\
\hline Total & $\mathbf{0}$ & $\mathbf{0}$ & $\mathbf{0}$ & $\mathbf{3 8 9}$ & $\mathbf{6 3 5}$ & \multirow{2}{*}{$\mathbf{1 0 2 4}$} \\
\hline Percentage & $\mathbf{0 \%}$ & $\mathbf{0 \%}$ & $\mathbf{0 \%}$ & $\mathbf{3 8 \%}$ & $\mathbf{6 2 \%}$ & \\
\hline
\end{tabular}

Table 2. Recapitulation of customer expectations assessment

\begin{tabular}{|c|c|c|c|c|c|c|}
\hline \multirow{3}{*}{ Questions } & \multicolumn{5}{|c|}{ Number of answers } & \multirow{3}{*}{ Tota } \\
\hline & $\begin{array}{c}\text { Very } \\
\text { unimportant }\end{array}$ & Unimportant & $\begin{array}{c}\text { Quite } \\
\text { important }\end{array}$ & $\begin{array}{c}\text { Very } \\
\text { unimportant }\end{array}$ & Unimportant & \\
\hline & (1) & (2) & (3) & (4) & (5) & \\
\hline Variable 1 & 0 & 0 & 0 & 64 & 0 & 64 \\
\hline Variable 2 & 0 & 0 & 0 & 64 & 0 & 64 \\
\hline Variable 3 & 0 & 0 & 0 & 57 & 7 & 64 \\
\hline Variable 4 & 0 & 0 & 0 & 54 & 10 & 64 \\
\hline Variable 5 & 0 & 0 & 0 & 49 & 15 & 64 \\
\hline Variable 6 & 0 & 5 & 20 & 39 & 0 & 64 \\
\hline Variable 7 & 0 & 0 & 39 & 25 & 0 & 64 \\
\hline
\end{tabular}


International Journal of Engineering Research And Advanced Technology, Vol.5, Issue 3, March-2019

\begin{tabular}{|c|c|c|c|c|c|c|} 
Variable 8 & 0 & 0 & 15 & 49 & 0 & 64 \\
Variable 9 & 0 & 0 & 46 & 18 & 0 & 64 \\
\hline Variable 10 & 0 & 0 & 10 & 54 & 0 & 64 \\
\hline Variable 11 & 0 & 0 & 6 & 48 & 10 & 64 \\
\hline Variable 12 & 0 & 0 & 34 & 20 & 10 & 64 \\
\hline Variable 13 & 0 & 0 & 39 & 25 & 0 & 64 \\
\hline Variable 14 & 0 & 0 & 10 & 54 & 0 & 64 \\
\hline Variable 15 & 0 & 0 & 46 & 11 & 7 & 64 \\
\hline Variable 16 & 0 & 0 & 0 & 57 & 7 & 64 \\
\hline Total & $\mathbf{0}$ & $\mathbf{5}$ & $\mathbf{2 6 5}$ & $\mathbf{6 8 8}$ & $\mathbf{6 6}$ & \multirow{2}{*}{$\mathbf{1 0 2 4}$} \\
\cline { 1 - 3 } Percentage & $\mathbf{0 . 0 \%}$ & $\mathbf{0 . 5 \%}$ & $\mathbf{2 5 . 9 \%}$ & $\mathbf{6 7 . 2 \%}$ & $\mathbf{6 . 4 \%}$ & \\
\hline
\end{tabular}

In table 2 there are $0.5 \%$ of customers who feel dissatisfied with the performance that has been given. This dissatisfaction occurs in variable 9 related to the timeliness in making certificate of test results. In this study the validity test for the Hopeful Questionnaire and also the Actual Questionnaire were used to measure customer satisfaction with the following results:

Table 3. Test the Validity of the Hopeful Questionnaire

\begin{tabular}{|c|c|c|c|}
\hline Variable & $\begin{array}{c}\text { Value of r } \\
\text { (Calculate) }\end{array}$ & $\begin{array}{c}\text { The value of r (Table) } \\
\mathbf{n}=\mathbf{6 4} \mathbf{\alpha} \mathbf{0 . 0 5}\end{array}$ & Status \\
\hline Variable 1 & 0.680 & 0.246 & Valid \\
\hline Variable 2 & 0.753 & 0.246 & Valid \\
\hline Variable 3 & 0.753 & 0.246 & Valid \\
\hline Variable 4 & 0.711 & 0.246 & Valid \\
\hline Variable 5 & 0.711 & 0.246 & Valid \\
\hline Variable 6 & 0.680 & 0.246 & Valid \\
\hline Variable 7 & 0.874 & 0.246 & Valid \\
\hline Variable 8 & 0.729 & 0.246 & Valid \\
\hline Variable 9 & 0.800 & 0.246 & Valid \\
\hline Variable 10 & 0.652 & 0.246 & Valid \\
\hline Variable 11 & 0.652 & 0.246 & Valid \\
\hline Variable 12 & 0.680 & 0.246 & Valid \\
\hline Variable 13 & 0.874 & 0.246 & Valid \\
\hline Variable 14 & 0.680 & 0.246 & Valid \\
\hline Variable 15 & 0.652 & 0.246 & Valid \\
\hline Variable 16 & 0.680 & 0.246 & Valid \\
\hline
\end{tabular}

Table 4. Test the Validity of the Actual Questionnaire

\begin{tabular}{|c|c|c|c|}
\hline Variabel & $\begin{array}{c}\text { Value of } \mathbf{r} \\
\text { (Calculate) }\end{array}$ & $\begin{array}{c}\text { The value of } \mathbf{r} \text { (Table) } \\
\mathbf{n}=\mathbf{6 4} \mathbf{\alpha ~ \mathbf { ~ 0 5 }}\end{array}$ & Status \\
\hline Variable 1 & 0.578 & 0.246 & Valid \\
\hline Variable 2 & 0.678 & 0.246 & Valid \\
\hline Variable 3 & 0.541 & 0.246 & Valid \\
\hline Variable 4 & 0.604 & 0.246 & Valid \\
\hline
\end{tabular}


International Journal of Engineering Research And Advanced Technology, Vol.5, Issue 3, March-2019

After the

\begin{tabular}{|c|c|c|c|}
\hline Variable 5 & 0.479 & 0.246 & Valid \\
\hline Variable 6 & 0.656 & 0.246 & Valid \\
\hline Variable 7 & 0.690 & 0.246 & Valid \\
\hline Variable 8 & 0.408 & 0.246 & Valid \\
\hline Variable 9 & 0.727 & 0.246 & Valid \\
\hline Variable 10 & 0.786 & 0.246 & Valid \\
\hline Variable 11 & 0.690 & 0.246 & Valid \\
\hline Variable 12 & 0.515 & 0.246 & Valid \\
\hline Variable 13 & 0.794 & 0.246 & Valid \\
\hline Variable 14 & 0.690 & 0.246 & Valid \\
\hline Variable 15 & 0.605 & 0.246 & Valid \\
\hline Variable 16 & 0.477 & 0.246 & \\
\hline
\end{tabular}

Expectation Questionnaire and the Actual Questionnaire are Valid, the Reliability test is conducted. The following are the results of the Reliability Test:

Table 5. Reliability Test

\begin{tabular}{|l|c|c|c|c|}
\hline \multicolumn{1}{|c|}{ Data Type } & $\begin{array}{c}\text { Valid Number of } \\
\text { Variables }\end{array}$ & $\begin{array}{c}\text { The value of } \boldsymbol{\alpha} \text { is } \\
\text { calculated }\end{array}$ & $\begin{array}{c}\text { Range Alpha } \\
\text { Cronbach }\end{array}$ & Status \\
\hline Expectation & 16 & 0.93 & $>0.6$ & Reliabel \\
\hline Actualization & 16 & 0.88 & $>0.6$ & Reliabel \\
\hline
\end{tabular}

In the Statistical Test two tests were carried out namely the Adequacy Test and the Uniformity Test Data on the expectation questionnaire and the actual questionnaire, along with the results of the two Tests[8, 16]:

- Test of Expectation Questionnaire Data Adequacy

$$
\begin{aligned}
& N^{\prime}=\left[\frac{\frac{k}{s} \sqrt{N \sum x^{2}-\left(\sum x\right)^{2}}}{\sum x}\right]^{2}=\left[\frac{\frac{2}{0.05} \sqrt{64(1.165 .542)-(74.338 .884)}}{8622}\right]^{2} \\
& N^{\prime}=\mathbf{5}, \mathbf{5 1}=\mathbf{6}
\end{aligned}
$$

Data Adequacy Test Results compared to the two questionnaires show the $\mathrm{N}$ value is smaller than N. So that the collected data is declared sufficient and representing the population.

\begin{tabular}{|c|c|c|c|c|c|}
\hline \multicolumn{5}{|c|}{ Questionnaire $n=64$, trust $95 \%$} & \multirow{2}{*}{ Note } \\
\hline I-variable & $\mathrm{LCL}$ & Min data & Max Data & $\mathrm{UCL}$ & \\
\hline 1 & 6.40 & 7 & 10 & 10.54 & Uniform \\
\hline 2 & 6.25 & 7 & 9 & 10.37 & Uniform \\
\hline 3 & 5.74 & 7 & 10 & 11.04 & Uniform \\
\hline 4 & 7.05 & 7 & 10 & 10.51 & Uniform \\
\hline 5 & 6.79 & 7 & 10 & 11.12 & Uniform \\
\hline 6 & 5.11 & 6 & 10 & 10.92 & Uniform \\
\hline 7 & 5.41 & 7 & 10 & 10.53 & Uniform \\
\hline 8 & 6.75 & 8 & 10 & 10.87 & Uniform \\
\hline 9 & 5.54 & 7 & 10 & 10.37 & Uniform \\
\hline
\end{tabular}

Table 6. Data Uniformity Test on the Expectation and Actual Questionnaire 
International Journal of Engineering Research And Advanced Technology, Vol.5, Issue 3, March-2019

\begin{tabular}{|l|c|c|c|c|c|}
10 & 6.55 & 7 & 10 & 10.95 & Uniform \\
\hline 11 & 5.88 & 7 & 10 & 10.81 & Uniform \\
\hline 12 & 6.47 & 7 & 10 & 10.47 & Uniform \\
\hline 13 & 5.81 & 7 & 9 & 9.97 & Uniform \\
\hline 14 & 6.32 & 7 & 10 & 10.83 & Uniform \\
\hline 15 & 5.75 & 7 & 10 & 10.84 & Uniform \\
\hline 16 & 6.89 & 8 & 10 & 10.67 & Uniform \\
\hline
\end{tabular}

\subsection{Calculation of Score and Value of Hope Questionnaire and Actual Questionnaire}

After processing, the data will be calculated by the number of Scores and Expectations and the actual value. The amount is categorized according to the number of scores calculated based on the answers multiplied by the weight scale on the questionnaire such as the following tebel:

Table 7. Satisfaction / Interest Score Table

\begin{tabular}{|l|c|c|}
\hline \multicolumn{1}{|c|}{ Category } & Score $\left(\sum\right.$ Respondent x Scale $)$ & Standard value \\
\hline Very Important/Satisfied & $64 \times 5=320$ & $>256$ \\
\hline Important/Satisfied & $64 \times 4=256$ & $192-\leq 256$ \\
\hline Important enough/Satisfied & $64 \times 3=192$ & $129-\leq 192$ \\
\hline Unimportant/Satisfied & $64 \times 2=128$ & $65-\leq 128$ \\
\hline Very Unimportant/Satisfied & $64 \times 1=64$ & $0-\leq 64$ \\
\hline
\end{tabular}

Table 8. Total Score and Expectation Value

\begin{tabular}{|c|c|c|c|}
\hline Question Item & Score Value (Yi) & Expectation Value (Yi) & Conclusion \\
\hline 1 & 294 & 4.59 & Very Important \\
\hline 2 & 287 & 4.48 & Very Important \\
\hline 3 & 284 & 4.44 & Very Important \\
\hline 4 & 315 & 4.92 & Very Important \\
\hline 5 & 315 & 4.92 & Very Important \\
\hline 6 & 298 & 4.66 & Very Important \\
\hline 7 & 277 & 4.33 & Very Important \\
\hline 8 & 295 & 4.61 & Very Important \\
\hline 9 & 288 & 4.50 & Very Important \\
\hline 10 & 308 & 4.81 & Very Important \\
\hline 11 & 308 & 4.81 & Very Important \\
\hline 12 & 294 & 4.55 & Very Important \\
\hline 13 & 277 & 4.33 & Very Important \\
\hline 14 & 298 & 4.66 & Very Important \\
\hline 15 & 305 & 4.77 & Very Important \\
\hline 16 & 288 & 4.50 & Very Important \\
\hline
\end{tabular}


International Journal of Engineering Research And Advanced Technology, Vol.5, Issue 3, March-2019

Table 9. Amount of Actual Scores and Values

\begin{tabular}{|c|c|c|c|}
\hline Question Item & 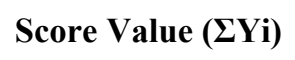 & Expectation Value (Yi) & Conclusion \\
\hline 1 & 246 & 3.84 & satisfied \\
\hline 2 & 244 & 3.81 & satisfied \\
\hline 3 & 249 & 3.89 & satisfied \\
\hline 4 & 250 & 3.91 & satisfied \\
\hline 5 & 261 & 4.08 & Very satisfied \\
\hline 6 & 217 & 3.39 & satisfied \\
\hline 7 & 230 & 3.59 & satisfied \\
\hline 8 & 268 & 4.19 & Very satisfied \\
\hline 9 & 221 & 3.45 & satisfied \\
\hline 10 & 256 & 4.00 & satisfied \\
\hline 11 & 230 & 3.59 & satisfied \\
\hline 12 & 246 & 3.84 & satisfied \\
\hline 13 & 225 & 3.52 & satisfied \\
\hline 14 & 253 & 3.95 & satisfied \\
\hline 15 & 227 & 3.55 & satisfied \\
\hline 16 & 266 & 4.16 & Very satisfied \\
\hline
\end{tabular}

\section{Calculation of SERVQUAL Value}

The following is a recapitulation of the SERVQUAL value of all variables:

Table 10. SERVQUAL Value

\begin{tabular}{|c|c|c|c|}
\hline Question & Actual Value & Expectation Value & Gap ( SERVQUAL Score) \\
\hline Variable 1 & 3.84 & 4.59 & -0.7463 \\
\hline Variable 2 & 3.81 & 4.48 & -0.6675 \\
\hline Variable 3 & 3.89 & 4.44 & -0.5494 \\
\hline Variable 4 & 3.91 & 4.92 & -1.0138 \\
\hline Variable 5 & 4.08 & 4.92 & -0.8419 \\
\hline Variable 6 & 3.39 & 4.66 & -1.2694 \\
\hline Variable 7 & 3.59 & 4.33 & -0.7363 \\
\hline Variable 8 & 4.19 & 4.61 & -0.4225 \\
\hline Variable 9 & 3.45 & 4.50 & -1.0469 \\
\hline Variable 10 & 4.00 & 4.81 & -0.8100 \\
\hline Variable 11 & 3.59 & 4.81 & -1.2163 \\
\hline Variable 12 & 3.84 & 4.55 & -0.7063 \\
\hline Variable 13 & 3.52 & 4.33 & -0.8144 \\
\hline Variable 14 & 3.95 & 4.66 & -0.7069 \\
\hline Variable 15 & 3.55 & 4.77 & -1.2231 \\
\hline Variable 16 & 4.16 & 4.50 & -0.3438 \\
\hline
\end{tabular}

From the above calculation the biggest gap value is found in variable 6 which is equal to -1.27 . This gap occurs because the actualization given to customers is not as expected. 


\subsection{Importance Performance Analysis (IPA) Diagram}

Quadrant I (Concentrate here), is an area that contains factors that are considered important by the customer but in fact the performance performed is not in accordance with customer expectations. Attributes in this quadrant must increase[17]. In quadrant I there are 3 variables, among others, variables 6.11 and 15 .

The timeliness of making a test certificate that is included in quadrant I shows the stronger or more priority variable 6 is to make improvements in terms of service quality. Whereas what happened to variables 11 and 15 needed to be improved a little.

Quadrant II (Keep up the good work), In quadrant II there are 4 variables, namely variables 4.5,10 and 14 . Data security in conducting testing in the XYZ Laboratory becomes an achievement that has been owned. The distribution of certified test parameters is also one of the achievements in the service that has been carried out by XYZ Laboratory so that consumers who do the testing are not worried because the results have been verified by KAN (National Accreditation Committee)[18-20]. Hygiene and manners applied to administrative services also affect achievement with cleanliness and courtesy provided that the customer feels comfortable and happy, so that the service at XYZ Laboratory has added value than the customers who come.

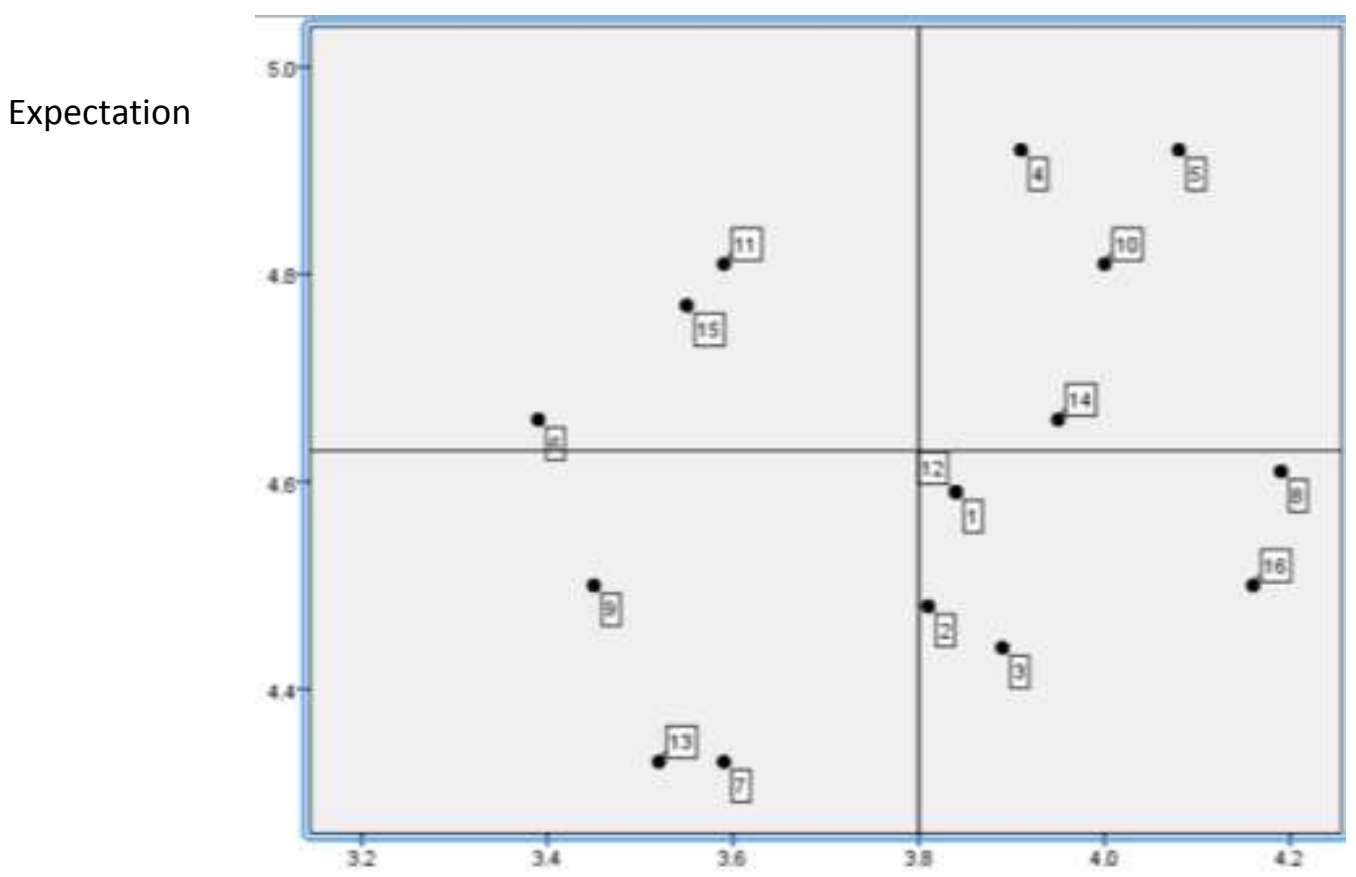

Actual

Figure 3. Importance Performance Analysis Diagram

Quadrant III (Low Priority), is a region that is considered less important by customers and its performance is indeed not too special. In this quadrant III variables number 9.13 and 7 are considered important by the customer and also the resulting performance is not satisfactory.

Quadrant IV (Possible to kill), In this quadrant there are 5 variables that are considered less important by the customer but the resulting performance exceeds customer expectations or can be said to be excessive.

\section{IV.CONCLUSION}

In this study the authors concluded that $19 \%$ of customers stated that "very satisfied" with the service received, while $81 \%$ stated "satisfied" with the service received. The results of the analysis rather than data processing can be concluded that the average SERVQUAL value than the expectation of customer expectations is 4.62 while the actuality or performance value is obtained by the SERVQUAL value of 3.80. If calculated by the SERVQUAL formula (Actual Value - Expectation Value) the Gap is obtained at -0.82 . This gap occurs because the performance produced does not meet customer expectations. From all 16 variables used to measure customer satisfaction, the overall results are minus. The entire Gap is divided into 4 quadrants in the Science Chart discussed in the previous chapter. After being analyzed using the Science Chart, the main priority for improvement is in variables 6, 11 and 15. Priority number 1 is in variable 6 where the Gap value is -1,269. Variable 6 is timeliness in making the test results certificate where $0.5 \%$ of customers feel dissatisfied with the performance that has been given by the employee. The Food Testing Laboratory needs to do a number of factors that have been presented in the previous chapter, which factors most often cause inaccuracies in making the test results certificate. Then for other priority improvements, the step that needs to be done 
is to analyze what factors are causing nonconformities, so that the Food Testing Laboratory can continue to improve the quality of services delivered to customers.

\section{REFERENCES}

[1] M. Rizki, and O. Sianipar, "Mutu Layanan Menurut Pelanggan Laboratorium Klinik (Service Quality Regarding to The Clinical Laboratory Customer)," Indonesian Journal Of Clinical Pathology And Medical Laboratory, vol. 21, no. 3, pp. 313-318, 2018.

[2] M. Plebani, "Clinical laboratory: bigger is not always better,” Diagnosis, vol. 5, no. 2, pp. 41-46, 2018.

[3] N. A. P. Pedraza, J. I. P. Montealegre, and R. R. Serrezuela, "Feasibility Analysis for Creating a Metrology Laboratory Serving the Agribusiness and Hydrocarbons in the Department of Huila, Colombia," International Journal of Applied Engineering Research, vol. 13, no. 6, pp. 3373-3378, 2018.

[4] R. Kearney, Public sector performance: management, motivation, and measurement: Routledge, 2018.

[5] V. M. Chabalengula, F. Mumba, and S. Mbewe, "How pre-service teachers' understand and perform science process skills," Eurasia Journal of Mathematics, Science \& Technology Education, vol. 8, no. 3, pp. 167-176, 2012.

[6] P. Hastuti, A. Irianto, and T. Izzati, "Factors That Affect Learning Difficulties Of Subjects Related To Economics For The First Year Senior High School In The Boarding Schools, Padang Panjang-West Sumatera," Science International, vol. 27, no. 3, pp. 2477-2479, 2015.

[7] P. Hastuti, and T. Izzati, “The Control Process Skills Of Introduction Accounting Subject For Student In Department Of Economic Education Faculty To Fulfill The Industrial Needs," Science International, vol. 28, no. 4, pp. 1143-146, 2016.

[8] B. G. Dale, and J. J. Plunkett, Quality costing: Routledge, 2017.

[9] J. Dlačić, "Book review: The Routledge Handbook of Consumer Behaviour in Hospitality and Tourism (Edited by Saurabh Kumar Dixit)," Tourism and hospitality management, vol. 23, no. 2, pp. 297, 2017.

[10] N. Hill, and J. Alexander, The handbook of customer satisfaction and loyalty measurement: Routledge, 2017.

[11] M. F. Alhameiddhi, “Analisis Kepuasan Pasien terhadap Kualitas Layanan Rumah Sakit Umum Natama Kota Tebing Tinggi Menggunakan Metode Fuzzy SERVQUAL,” 2018.

[12] R. Andalusi, "Pengaruh Kualitas Pelayanan, Harga, Dan Kualitas Produk Terhadap Kepuasan Pelanggan Instrumen Penunjang Laboratorium,” Jurnal Madani, vol. 1, no. 2, pp. 305-322, 2018.

[13] T. Izzati, P. Hastuti, I. Gunawan et al., “An Education Profile Of Indonesian Youth In 2009-2013,” Science International, vol. 27, no. 2, pp. 1457-1460, 2015.

[14] A. Hidayah, and S. Sumiyarsih, "Dampak ketidakpuasan konsumen pada sikap konsumen berdasarkan dimensi kualitas jasa dan perbedaan karakteristik demografi,” Jurnal Perilaku dan Strategi Bisnis, vol. 6, no. 1 Februari, pp. 47-57, 2018.

[15] J. E. Ross, Total quality management: Text, cases, and readings: Routledge, 2017.

[16] F. Franceschini, Advanced quality function deployment: CRC Press, 2016.

[17] Y. Yang, P. K. Lee, and T. Cheng, "Continuous improvement competence, employee creativity, and new service development performance: A frontline employee perspective," International Journal of Production Economics, vol. 171, pp. 275-288, 2016.

[18] K. Hort, H. Djasri, and A. Utarini, "Regulating the quality of health care: Lessons from hospital accreditation in Australia and Indonesia," The Nossal Institute for Global Health, Working Paper Series, vol. 28, 2013.

[19] P. o. Indonesia, "Undang-Undang Republik Indonesia Nomor 7 Tahun 1996 tentang Pangan," President, ed., Republic of Indonesia Government, 199.

[20] P. R. Indonesia, "Peraturan Pemerintah Republik Indonesia Nomor 102 Tahun 2000 tentang Standardisasi Nasional," Jakarta, 2000. 